\title{
STRATEGI MENINGKATKAN EFISINESI DAN EFEKTIVITAS KINERJA KEUANGAN PEMERINTAH KOTA BOGOR DALAM PENGELOLAAN APBD
}

\author{
Strategy Increased Efficiency and Effectiveness of Bogor City Government Finance Performance in \\ Managing the Budgetary of Regional Revenue and Expenditure
}

Muhamad Syauqi', Hermanto Siregar², Yusman Syaukat ${ }^{3}$

\author{
1Staff Biro Perencanaan dan Keuangan Kementerian Pariwisata. Email: difla_2000@yahoo.com \\ 2Staff Pengajar Departemen Ilmu Ekonomi, Fakultas Ekonomi dan Manajemen, IPB. Email: \\ hermansiregar@yahoo.com \\ 2Staff Pengajar Departemen Ekonomi Sumberdaya dan Lingkungan, Fakultas Ekonomi dan Manajemen, IPB. \\ Email: ysyaukat@apps.ipb.ac.id
}

\begin{abstract}
Financial performance and budgetary realization is one of the most important keys into the progress of an organization. Hhealthy or not can be marked from the financial performance that showed by the financial statements, that's would be the source of organizational decisions in the future of financial side. The purpose of this research to analysis the finance performance of Bogor city government that measured with regional finance ratio, identifies the factors are affecting finance performance Bogor city ggovernment, formulate the strategies and policies in order to increasing efficiency and effectiveness the finance performance of Bogor city government in managing of the budgetary of regional revenue and expenditure. This research applied descriptive analysis, quantitatively using multiple regression method and analytical hierarchy process. The result makes the point that the finance performance of Bogor city government has unstable yet. This measured by the indicator i.e less fiscal decentralization has given dependency to the central government very high. There have the variables influence between investment, percapita income, local taxes that had a positive and gross regional domestic product (PDRB) has a negative impact also significant influence toward the financial performance. The priority sequences of strategies to improve the efficiency and effectiveness of Bogor Government finance performance with analytical hierarchy process method as follows: (1) increasing the supervision; (2) education and training; (3) communication and commitment to achieve the goals; (4) implementation the incentive and disincentive regulations; (5) intensification and intensification of taxes and local retribution
\end{abstract}

Keywords: Efficiency and Effectiveness, Financial Performance, Bogor City Government, Budgetary of Regional Revenue and Expenditure

\begin{abstract}
ABSTRAK
Kinerja keuangan dan realisasi anggaran merupakan salah satu kunci dalam kemajuan suatu organisasi. Sehat atau tidaknya suatu organisasi dapat dinilai dari kinerja keuangan ditunjukkan oleh laporan keuangan, hal itu yang akan menjadi sumber keputusan organisasi di masa mendatang dari sisi finansial. Tujuan dari penelitian ini adalah menganalisis kinerja keuangan pemerintah Kota Bogor yang diukur dengan rasio keuangan daerah, mengindentifikasi faktor-faktor yang mempengaruhi kinerja keuangan pemerintah Kota Bogor, merumuskan strategi dan kebijkan untuk meningkatkan efisiensi dan efektivitas kinerja keuangan pemerintah Kota Bogor dalam pengelolaan APBD. Penelitian ini menggunakan analisis deskriptif, analisis kuantitatif menggunakan metode regresi linier berganda dan AHP. Hasilnya menunjukkan bahwa kinerja keuangan pemerintah Kota Bogor belum stabil. Hal ini ditunjukkan oleh indikator desentralisasi fiskal kurang mengingat ketergantungan keuangan terhadap pemerintah pusat sangat tinggi. Ada pengaruh antara variabel investasi, pendapatan perkapita, pajak daerah mempunyai pengaruh yang positif dan PDRB mempunyai pengaruh yang negatif signifikan terhadap kinerja keuangan. Urutan prioritas strategi meningkatkan efisiensi dan efektivitas kinerja keuangan pemerintah Kota Bogor dengan metode AHP adalah sebagai berikut: 1. meningkatkan pengawasan, 2. Pendidikan dan pelatihan, 3. komunikasi dan komitmen pencapaian sasaran, 4. penerapan regulasi insentif dan disinsentif, 5.intensifikasi dan ekstensifikasi pajak dan retribusi daerah.
\end{abstract}

Kata Kunci: Efisiensi Dan Efektivitas, Kinerja Keuangan, Pemerintah Kota Bogor, APBD 


\section{PENDAHULUAN}

Paradigma pengelolaan keuangan daerah telah mengalami perubahan yang sangat mendasar sejak di terapkannya otonomi daerah pada tahun 2001. Undang-undang nomor 32 tahun 2004 yang telah direvisi menjadi undangundang nomor 23 tahun 2014 tentang pemerintahan daerah dan undang-undang nomor 33 tahun 2004 tentang perimbangan keuangan antara pemerintah pusat dan pemerintah daerah menjadi landasan utama dalam pelaksanaan otonomi daerah. Tujuan otonomi daerah secara umum adalah untuk meningkatkan kemandirian daerah, memperbaiki transparansi dan akuntabilitas publik atas pengelolaan keuangan daerah, meningkatkan responsivitas pemerintah terhadap kebutuhan publik, meningkatkan partisipasi publik dalam pembangunan daerah, meningkatkan efisiensi dan efektivitas pengelolaan keuangan dan pelayanan publik, serta mendorong demokratisasi di daerah (Mahmudi 2009).

Pemberian otonomi yang luas dan desentralisasi fiskal membuka jalan bagi pemerintah untuk melakukan pengelolaan keuangan daerah yang berorientasi pada kepentingan publik. Jika pengelolaan keuangan daerah dilakukan secara ekonomis, efisien, efektif, transparansi, akuntabilitas dan berkeadilan dapat mendorong pertumbuhan ekonomi suatu daerah. Sehingga keuangan daerah merupakan salah satu unsur yang penting dalam menyelenggarakan pemerintahan dan pembangunan daerah. Untuk pengelolaan keuangan daerah dibutuhkan sumber daya ekonomi berupa keuangan yang di tuangkan dalam suatu anggaran pemerintah daerah.

Pengelolaan keuangan yang di tuangkan dalam Anggaran Pendapatan dan Belanja Daerah (APBD) yang 2 langsung maupun tidak langsung mencerminkan kemampuan pemerintah daerah dalam membiayai pelaksanaan tugas-tugas pemerintahan, pembangunan dan pelayanan sosial masyarakat. Anggaran pendapatan dan belanja daerah (APBD) merupakan instrumen kebijakan yang utama bagi pemerintah daerah. Anggaran pendapatan dan belanja daerah dalam era otonomi daerah di susun dengan pendekatan kinerja. Anggaran dengan pendekatan kinerja adalah suatu sistem anggaran yang mengutamakan kepada upaya pencapaian hasil kinerja atau output dari perencanaan alokasi biaya atau input yang di tetapkan (Mardiasmo 2002).

Prinsip-prinsip yang mendasari dalam hal pengelolaan keuangan daerah, yaitu transparansi, akuntabilitas, dan value for money. Transparansi adalah keterbukaan dalam proses perencanaan, penyusunan, dan pelaksanaan anggaran daerah. Hal tersebut memberikan arti bahwa anggota masyarakat memiliki hak dan akses yang sama untuk mengetahui proses anggaran karena menyangkut aspirasi dan kepentingan masyarakat, terutama pemenuhan kebutuhan hidup masyarakat. Akuntabilitas adalah pertanggungjawaban publik yang berarti bahwa proses penganggaran mulai perencanaan, penyusunan, dan pelaksanaan harus benar-benar dapat dilaporkan dan dipertanggungjawabkan kepada DPRD dan masyarakat. Masyarakat tidak hanya memiliki hak untuk mengetahui anggaran tersebut, tetapi juga berhak menuntut pertanggungjawaban atas rencana ataupun pelaksanaan anggaran tersebut. Value for money adalah diterapkannya tiga prinsip dalam proses penganggaran yaitu ekonomi, efisiensi, dan efektivitas. Ekonomi berkaitan dengan pemilihan dan penggunaan sumber daya dalam jumlah dan kualitas tertentu pada harga yang paling murah. Efisiensi berarti penggunaan dana masyarakat (public money) tersebut menghasilkan output yang maksimal atau berdaya guna. 
Efektivitas berarti bahwa penggunaan anggaran tersebut harus mencapai target atau tujuan untuk kepentingan publik (Mardiasmo 2002). Pengalokasian anggaran pada APBD khususnya dengan pendekatan alokatif efisiensi dan efektivitas pada akhirnya menjadi salah satu agenda penting bagi setiap instansi pemerintah, baik pusat maupun daerah dalam rangka mendukung reformasi keuangan negara yang telah dicanangkan, termasuk di dalamnya sebagai pengemban amanat ini adalah Pemerintah Kota Bogor.

Tabel 1. Ringkasan APBD Kota Bogor Tahun 2011 s/d 2014 (miliar rupiah)

\begin{tabular}{|c|c|c|c|c|c|c|c|c|c|c|}
\hline \multirow[t]{2}{*}{ No } & \multirow[t]{2}{*}{ Uratan } & \multicolumn{2}{|c|}{2011} & \multicolumn{2}{|c|}{2012} & \multicolumn{2}{|c|}{2013} & \multicolumn{2}{|c|}{2012} & \multirow{2}{*}{$\begin{array}{l}\text { Ratr- } \\
\text { rota }\end{array}$} \\
\hline & & Ancearan & Aeal sas & Aneporn & Realsas & Anegarn & Rezisas & Angeran & fea isas & \\
\hline 5 & Fendaputan Daerah & & & & & & & & & \\
\hline 21 & PAD & 200.43 & 230.44 & 252220 & 300.93 & 400,67 & 464,69 & 433,01 & 54435 & 385.22 \\
\hline \multirow[t]{2}{*}{112} & 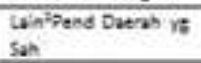 & 52168 & 308,97 & 349.57 & 313,95 & 530,52 & 316,70 & 406,99 & 357,21 & 313,20 \\
\hline & $\begin{array}{l}\text { Jumian Fendaputan } \\
\text { Deereh }\end{array}$ & $1.112,51$ & 1141.63 & 1534.12 & $2.356,52$ & 1531,68 & 1.574 .37 & 1753.51 & 1.757 .89 & $1,457,55$ \\
\hline 24 & Bean a Tde Letures & 679.22 & 65134 & 70358 & 873,88 & 826,18 & 759.52 & 85093 & 779.94 & 716.170 \\
\hline \multirow[t]{3}{*}{2.2} & Beinja teriuns & 50437 & 423,23 & 697,75 & 58232 & 84199 & 662.50 & 1141.34 & 923.12 & 647,79 \\
\hline & $\begin{array}{l}\text { Jumiah Deasia } \\
\text { Deerah }\end{array}$ & 1.13359 & 107257 & 1.401 .32 & 1.256 .20 & $1.669,17$ & 1.42215 & 1992,32 & 1.702 .96 & 1363.96 \\
\hline & SurplatDefist & $(71,27)$ & 67.06 & 367,201 & 100.32 & $(13650)$ & 152.23 & 23931 & 5473 & $935 a$ \\
\hline
\end{tabular}

Sumber: Laporan Realisasi APBD Kota Bogor 2011-2014 BPKAD, 2015

Tabel 1 menunjukkan bahwa selama empat tahun terakhir penyerapan anggaran pada APBD Kota Bogor terus mengalami trend penurunan. Anggaran yang tidak terserap dari APBD Kota Bogor pada tahun 2011 sebesar Rp 67,06 miliar lalu menurun kembali menjadi $\mathrm{Rp}$ 100,32 miliar di tahun 2012. Jika di rataratakan pertahun anggaran yang tidak serap pada APBD Kota Bogor selama empat tahun terakhir sebesar Rp 93,58 miliar. Kegagalan dalam mencapai target penyerapan anggaran mengindikasikan telah terjadinya inefisiensi dan inefektivitas dalam pengalokasi anggaran di Kota Bogor. Banyaknya anggaran APBD yang tidak terserap akan berdampak langsung maupun tidak langsung terhadap pelayanan dasar publik seperti pendidikan, kesehatan, pembukaan lapangan kerja baru dan juga pertumbuhan ekonomi di Kota Bogor.

Tabel 2. Rasio Tingkat Efisiensi Pendapatan Daerah Pemerintah Kota Bogor TA 2011-2014

\begin{tabular}{|l|c|c|c|c|}
\hline Tahun & $\begin{array}{c}\text { Total Realisasi } \\
\text { Pendapatan } \\
\text { Daerah } \\
\text { (miliar rupiah) }\end{array}$ & $\begin{array}{c}\text { Total Realisasi } \\
\text { Belanja Daerah } \\
\text { (miliar rupiah) }\end{array}$ & $\begin{array}{c}\text { Rasio } \\
\text { (BD/PD) } \\
\%\end{array}$ & $\begin{array}{c}\text { Kriteria } \\
\text { Efisiensi }\end{array}$ \\
\hline 2011 & $1.141,63$ & $1.074,57$ & 94,12 & Kurang Efisien \\
\hline 2012 & $1.356,52$ & $1.256,20$ & 92,60 & Kurang Efisien \\
\hline 2013 & $1.574,37$ & $1.422,13$ & 90,33 & Kurang Efisien \\
\hline 2014 & $1.757,69$ & $1.702,96$ & 96,88 & Kurang Efisien \\
\hline Rata-rata & $1.457,55$ & $1.363,97$ & 93,58 & Kurang Efisien \\
\hline
\end{tabular}

Sumber: Laporan Realisasi APBD Kota Bogor 2011-2014 BPKAD, diolah 2015.

Berdasarkan Tabel 2, Pemerintah Kota Bogor kurang efisien dalam membelanjakan anggaran belanja daerah. Rasio tingkat efisiensi pendapatan daerah menjadi indikator bagi pemerintah daerah dalam melakukan pemungutan pendapatan. Pemerintah daerah dituntut untuk dapat bertindak efisien sehingga perbandingan biaya yang dikeluarkan untuk memperoleh pendapatan dengan besarnya pendapatan yang diterima bersifat rasional. Semakin rendah biaya 
yang dikeluarkan pemerintah dalam menjaring pendapatan dari $\mathrm{PAD}$, maka pemerintah daerah masuk dalam kategori efisien (Mahmudi 2010).

Tabel 3, menjelaskan bahwa tingkat efektivitas belanja daerah pemerintah Kota Bogor baru berada pada kriteria cukup efektif dalam membelanjakan anggaran belanja daerahnya. Rasio tingkat efektivitas belanja daerah berhubungan dengan derajat keberhasilan pemerintah terhadap kemampuannya dalam meyediakan pelayanan masyarakat yang merupakan sasaran yang telah ditetapkan sebelumnya melalui realisasi penyerapan anggaran belanja (Sumenge 2013).

Pengukuran kinerja sangat penting untuk menilai akuntabilitas pemerintah daerah dan pimpinan daerah dalam menghasilkan pelayanan publik yang lebih baik. Akuntabilitas bukan sekedar kemampuan untuk menunjukkan bagaimana uang publik di belanjakan, akan tetapi meliputi kemampuan menunjukkan bahwa uang publik tersebut telah di belanjakan secara ekonomis, efektif dan efisien. Berdasarkan RPJMD (rencana pembangunan jangka menengah daerah) Kota Bogor tahun 2015-2019 yang salah satu misinya mewujudkan pemerintahan yang bersih dan transparan melalui perbaikan kinerja keuangan dan akuntabilitas. Maka pertanyaan penelitian ini yang pertama adalah. Bagaimana kinerja keuangan pemerintah Kota Bogor di ukur dengan rasio keuangan daerah?dan yang kedua adalah faktorfaktor apa sajakah yang mempengaruhi kinerja keuangan pemerintah Kota Bogor?

Tabel 3. Rasio Tingkat Efektivitas Belanja Daerah Pemerintah Kota Bogor TA 2011-2014

\begin{tabular}{|c|c|c|c|c|}
\hline Tahun & $\begin{array}{c}\text { Total Anggaran } \\
\text { Belanja } \\
\text { Daerah } \\
\text { (miliar rupiah) }\end{array}$ & $\begin{array}{c}\text { Total Realisasi } \\
\text { Belanja } \\
\text { Daerah } \\
\text { (miliar rupiah) }\end{array}$ & $\begin{array}{c}\text { Rasio } \\
\text { (TRBD TABD) } \\
\%\end{array}$ & $\begin{array}{c}\text { Kriteria } \\
\text { Efektifitas }\end{array}$ \\
\hline 2011 & $1.183,79$ & $1.074,57$ & 90,77 & ef ektif \\
\hline 2012 & $1.401,32$ & $1.256,20$ & 89,64 & cukup efektif \\
\hline 2013 & $1.668,17$ & $1.422,13$ & 85,25 & cukup efektif \\
\hline 2014 & $1.992,82$ & $1.702,96$ & 85,45 & cukup efektif \\
\hline Rata-rata & $1.561,53$ & $1.363,97$ & 87,35 & cukup efektif \\
\hline
\end{tabular}

Sumber: Laporan Realisasi APBD Kota Bogor 2011-2014 BPKAD, diolah 2015.

Tabel 2 dan 3 menunjukkan bahwa kinerja keuangan Pemerintah Kota Bogor dalam pengelolaan APBD nya berdasarkan rasio tingkat efisiensi pendapatan daerah masih kurang efisien dan rasio tingkat efektivitas belanja daerahnya baru berada pada penilaian cukup efektif. Hal tersebut bertentangan dengan kebijakan walikota dan wakil walikota Bogor yang tercantum didalam RPJMD tahun 2015-2019 di mana memberi penekanan pada efisiensi dan relokasi anggaran. Berdasarkan hal tersebut maka pertanyaan penelitian ini yang ketiga adalah Bagaimana strategi dan kebijakan Pemerintah Kota Bogor untuk meningkatkan efisiensi dan efektivitas kinerja keuangan pemerintah Kota Bogor dalam pengelolaan APBD?

Berdasarkan latar belakang dan perumusan masalah, tujuan dari penelitian ini adalah:

1. Menganalisis kinerja keuangan pemerintah Kota Bogor di ukur dengan rasio keuangan daerah.

2. Mengindentifikasi faktor-faktor yang mempengaruhi kinerja keuangan pemerintah Kota Bogor. 
3. Merumuskan strategi dan kebijakan untuk meningkatkan efisiensi dan efektivitas kinerja keuangan pemerintah Kota Bogor dalam pengelolaan APBD.

\section{METODOLOGI}

Metode analisis yang digunakan dalam penelitian ini adalah

1. Analisis deskriptif

Analisis kinerja keuangan pemerintah Kota Bogor di analisis dengan menggunakan lima rasio keuangan daerah yaitu derajat desentralisasi fiskal, ketergantungan keuangan daerah, kemandirian keuangan daerah, pertumbuhan dan aktivitas.

2. Analisis regresi linier berganda

Perumusan model yang digunakan dalam penelitian ini diadopsi dari beberapa model hasil penelitian sebelumnya yang dilakukan oleh Lajdin (2008) yang menyatakan bahwa investasi berpengaruh positif dan signifikan terhadap kemandirian fiskal di Provinsi Sulawesi Tengah. Basir (2009) yang menyatakan bahwa PDRB berpengaruh positif dan signifikan terhadap kapasitas fiskal daerah di Kota Parepare. Suprajitno (2003) yang menyatakan bahwa pendapatan perkapita berpengaruh positif dan signifikan terhadap kemandirian fiskal di Kabupaten Banjarnegara. Florida (2006) yang menyatakan bahwa pajak daerah berpengaruh positif dan signifikan terhadap kinerja keuangan pemerintah Kabupaten/Kota di Provinsi Sumatra Utara. Model regresi yang digunakan dalam penelitian ini adalah:

$$
\begin{gathered}
\text { KKD }=\alpha+\beta_{1} I N V+\beta_{2} P D R B+\beta_{3} P P \\
+\beta_{4} P D+\varepsilon
\end{gathered}
$$

Keterangan:

$$
\begin{aligned}
\text { KDD }= & \text { Kinerja keuangan daerah dalam } \\
& \begin{array}{l}
\text { penelitian ini di proksikan } \\
\text { dengan rasio kemandirian }
\end{array} \\
& \text { keuangan daerah } \\
\alpha \quad= & \text { Intersep }
\end{aligned}
$$

$$
\begin{aligned}
& \beta \quad=\text { Koenfisien } \\
& \text { PP = Investasi (milyar rupiah) } \\
& \text { PDRB = Produk Domestik Regional } \\
& \text { bruto (milyar rupiah) } \\
& \text { PP = Pendapatan Perkapita (juta } \\
& \text { Rupiah) } \\
& \text { PD = Pajak Daerah (milyar rupiah) } \\
& \mathrm{E}=\text { Error }
\end{aligned}
$$

3. Analisis analytical hierarchi process (AHP) untuk merumuskan strategi.

\section{HASIL DAN PEMBAHASAN}

\section{Kinerja Keuangan Pemerintah Kota Bogor}

Berdasarkan hasil analisis dengan menggunakan rasio derajat desentralisasi fiskal rata-rata tingkat desentralisasi fiskal pemerintah Kota Bogor periode tahun anggaran 2005-2014 adalah 18,61 persen sehingga diklasifikasikan menurut kriteria penilaian tingkat desentralisasi fiskal adalah pemerintah Kota dengan tingkat desentralisasi fiskal kurang. Rata-rata tingkat ketergantungan keuangan daerah pemerintah Kota Bogor terhadap pemerintah pusat pada kurun waktu periode tahun anggaran 2005-2014 adalah 57,96 persen. Hal ini mengindikasikan bahwa kinerja PAD maupun sumber pendapatan lainnya belum optimal dalam membiayai aktifitas pembangunan daerah sehingga daerah sangat bergantung dengan adanya subsidi pemerintah melalui dana perimbangan. Maka dapat dikatakan bahwa tingkat ketergantungan keuangan daerah pemerintah Kota Bogor terhadap bantuan pemerintah pusat sangat tinggi.

Rata-rata tingkat kemandirian keuangan daerah pemerintah Kota Bogor selama periode tahun anggaran 20052014 adalah 31,31 persen sehingga diklasifikasikan menurut kriteria penilaian kemandirian keuangan daerah adalah pemerintah kota dengan tingkat kemandirian keuangan daerah sedang. PAD di Kota Bogor terus menunjukkan trend pertumbuhan dengan rata-rata pertumbuhan PAD 10 tahun terakhir di Kota Bogor sebesar 25,31 persen. Hal ini 
diakibatkan oleh pertumbuhan ekonomi di Kota Bogor yang semakin baik. Pertumbuhan belanja rutin Kota Bogor mengalami tren positif dalam arti dimana pertumbuhan belanja rutin yang semakin menurun setiap tahunnya sebesar 10.99 persen pertahun.

Berdasarkan hasil perhitungan rasio aktivitas dapat diketahui bahwa pada periode tahun anggaran 2005 sampai dengan tahun 2014 anggaran belanja daerah Kota Bogor lebih dominan dialokasikan untuk belanja rutin dengan rata-rata 59,75 persen. Porsi APBD yang dialokasikan untuk belanja rutin hampir selalu diatas 50 persen semakin tinggi persentase dana yang dialokasikan untuk belanja rutin berarti persentase belanja operasional untuk sarana dan prasarana ekonomi masyarakat cenderung semakin kecil. Hal tersebut menunjukkan bahwa selama 10 tahun terakhir APBD Kota Bogor lebih banyak dihabiskan untuk membiayai belanja rutin.

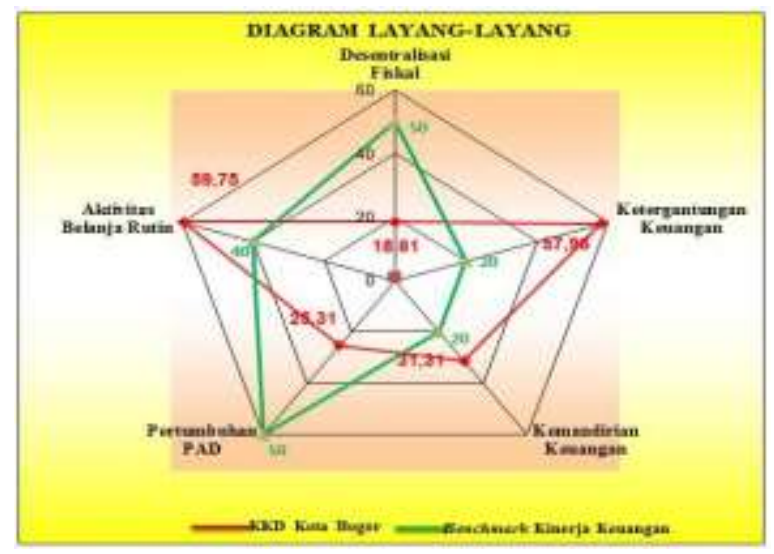

Gambar 7. Diagram layang-layang (kite diagram) kinerja keuangan pemerintah Kota Bogor

\section{Faktor-Faktor yang Mempengaruhi Kinerja Keuangan Pemerintah Kota Bogor}

Hasil analisis sebagaimana pada Tabel 4 menunjukan bahwa sekitar 99.7\% faktor-faktor yang mempengaruhi kinerja keuangan pemerintah Kota Bogor dapat dijelaskan oleh variabel independen, sedangkan sisanya $0.3 \%$ dijelaskan oleh sebab-sebab yang lain.
Keempat variabel berpengaruh nyata dan signifikan pada tingkat kepercayaan 5\% atau 0.05 . Lebih lanjut diketahui nilai $F$ statistik sebesar 0.000000 dengan nilai Significance of $F$ (P-Value) lebih kecil dari 0.05. Hal ini menunjukan bahwa model regresi yang diperoleh baik dan layak digunakan. Persamaan kinerja keuangan pemkot Bogor ini memenuhi empat asumsi dasar yaitu tidak mengalami gangguan ekonometrika baik itu multikolinieritas, normalitas, heteroskedastisitas dan autokorelasi.

Nilai investasi memiliki pengaruh yang signifikan terhadap kinerja keuangan pemkot Bogor sebagaimana ditunjukan oleh prob-nya (0.0015) yang lebih kecil dari 0.05. Sedangkan nilai koefisien variabel bernilai 1.227474 menunjukan bahwa investasi menunjukan pengaruh yang positif terhadap kinerja keuangan pemkot Bogor. Hal ini dapat dikatakan bahwa jika terjadi peningkatan investasi sebesar Rp 1 miliar rupiah maka akan menyebabkan kenaikan kinerja keuangan sebesar 1.227474 persen.

Investasi baik melalui penanaman modal dalam negeri (PMDN) maupun penanaman modal asing (PMA) akan mendorong pertumbuhan ekonomi. Pemerintah Kota Bogor perlu memfasilitasi berbagai aktivitas peningkatan perekonomian, salah satunya dengan membuka kesempatan berinvestasi karena investasi berpengaruh terhadap pertumbuhan ekonomi dan secara tidak langsung investasi akan berpengaruh terhadap penerimaan daerah. Meningkatnya penerimaan daerah akan berujung pada peningkatan kinerja keuangan pemerintah Kota Bogor.

PDRB memiliki pengaruh yang signifikan terhadap kinerja keuangan pemkot Bogor sebagaimana ditunjukan oleh prob-nya (0.0018) yang lebih kecil dari 0.05. Sedangkan nilai koefisien variabel bernilai -1.646975 menunjukan bahwa PDRB menunjukan pengaruh yang negatif terhadap kinerja keuangan 
pemkot Bogor. Hal ini dapat dikatakan bahwa jika terjadi peningkatan PDRB sebesar Rp 1 miliar maka akan menyebabkan penurunan kinerja keuangan sebesar 1.646975 persen. PDRB berpengaruh negatif terhadap kinerja keuangan karena sektor andalan atau leading sector perekonomian Kota Bogor masih didominasi oleh tiga sektor utama yakni perdagangan besar dan eceran; reparasi mobil dan sepeda motor, industri pengolahan, transportasi dan pergudangan. Peranan sektor-sektor tersebut secara total melebihi 50 persen dari total PDRB Kota Bogor. Ketiga sektor tersebut yang memiliki peranan yang cukup vital dalam pembentukan PDRB serta memberikan multiplier effect yang besar bagi pertumbuhan sektor ekonomi lainnya di Kota Bogor. Akan tetapi ketiga sektor tersebut tidak termasuk ke dalam jenis pajak daerah yang berhak di pungut pemerintah Kabupaten/Kota sebagaimana yang ditetapkan dalam undang-undang (closedlist) seperti pajak hotel, pajak restoran, pajak hiburan sehingga peningkatan pada PDRB Kota Bogor berpengaruh negatif terhadap kinerja keuangan pemerintah Kota Bogor.

Tabel 4. Faktor Penentu Kinerja Keuangan Pemerintah Kota Bogor.

\begin{tabular}{lrrrr}
\hline \multicolumn{1}{c}{ Variable } & Coefficient & Std. Error & t-Statistic & Prob. \\
\hline \multicolumn{1}{c}{ C } & -33436.12 & 14177.97 & -2.358315 & 0.0401 \\
INVESTASI & 1.227474 & 0.283564 & 4.328735 & 0.0015 \\
$\quad$ PDRB & -1.646975 & 0.389589 & -4.227467 & 0.0018 \\
$\quad 1.335716$ & 0.412614 & 3.237207 & 0.0089 \\
PENDAPATAN_PERKAPITA & 4.211011 & 0.192459 & 21.88008 & 0.0000 \\
$\quad$ PAJAK_DAERAH & 0.997785 & Mean dependent var & & 42780.33 \\
\hline \hline & 0.996898 & S.D. dependent var & 79201.01 \\
R-squared & 4410.877 & Akaike info criterion & & 19.88274 \\
Adjusted R-squared & 0.000000 & & \\
S.E. of regression & & & \\
Prob(F-statistic) & & & \\
\hline \hline
\end{tabular}

Keterangan: Signifikan pada taraf nyata $5 \%$

Pendapatan perkapita memiliki pengaruh yang signifikan terhadap kinerja keuangan pemkot Bogor sebagaimana ditunjukan oleh prob-nya (0.0089) yang lebih kecil dari 0.05 . Sedangkan nilai koefisien variabel bernilai 1.335716 menunjukan bahwa faktor pendapatan perkapita menunjukan pengaruh yang positif terhadap kinerja keuangan pemkot Bogor. Hal ini dapat dikatakan bahwa jika terjadi peningkatan pendapatan perkapita sebesar Rp 1 juta maka akan menyebabkan kenaikan kinerja keuangan sebesar 1.335716 persen. Salah satu faktor yang menyebabkan meningkatnya penerimaan daerah adalah meningkatnya tingkat hidup dan ekonomi masyarakat yang tercermin dalam pendapatan perkapita.
Meningkatnya pendapatan perkapita suatu daerah berarti semakin besar kemampuan masyarakat tersebut untuk membiayai pengeluaran pemerintahnnya. Pendapatan perkapita merupakan salah satu ukuran bagi kemakmuran suatu daerah, pendapatan perkapita seseorang yang semakin tinggi akan meningkatkan kemampuan seseorang untuk membayar (ability to pay) berbagai pungutan yang ditetapkan oleh pemerintah.

Pada tingkat distribusi pendapatan tertentu yang tetap semakin tinggi pendapatan perkapita rill suatu daerah, semakin besar pula kemampuan masyarakat daerah tersebut untuk membiayai pengeluaran rutin dan pengeluaran pembangunan pemerintahannya. Maka dapat dikatakan bahwa 
semakin tinggi pendapatan perkapita suatu daerah, semakin besar pula potensi sumber penerimaan daerah tersebut sehingga kemampuan masyarakat untuk membayar pajak yang meningkat. Maka semakin tinggi pendapatan perkapita suatu daerah berpengaruh positif terhadap kinerja keuangan.

Pajak daerah memiliki pengaruh yang signifikan terhadap kinerja keuangan pemkot Bogor sebagaimana ditunjukan oleh prob-nya (0.0000) yang lebih kecil dari 0.05. Sedangkan nilai koefisien variabel bernilai 4.211011 menunjukan bahwa pajak daerah menunjukan pengaruh yang positif terhadap kinerja keuangan pemkot Bogor. Hal ini dapat dikatakan bahwa jika terjadi peningkatan pajak daerah sebesar Rp 1 miliar maka akan menyebabkan kenaikan kinerja keuangan sebesar 4.211011 persen. Pajak daerah yang merupakan salah satu sumber penting PAD sangat berpengaruh pada kinerja keuangan pemerintah daerah. Hal ini sejalan dengan hasil penelitian Florida (2007) yang mengatakan bahwa pajak daerah berpengaruh positif dan signifikan terhadap kinerja keuangan. Karakterisitik pajak daerah yang terdiri dari banyak jenis seperti pajak hotel, pajak hiburan dan lain-lain menjadikan pajak daerah sebagai salah satu sumber kekuatan utama daerah dalam menggali pendapatan asli daerahnya (PAD), sehingga dapat dijelaskan penerimaan pajak daerah yang tinggi menunjukkan kinerja keuangan pemerintah daerah yang baik.

Tabel 5. Distribusi Persentase PDRB Atas Dasar Harga Berlaku Menurut Lapangan Usaha Kota Bogor Tahun 2010-2014 (Persen)

\begin{tabular}{|c|c|c|c|c|c|c|}
\hline Kategori & Uraim & 2010 & 2011 & 2012 & 2013 & 2014 \\
\hline (1) & (2) & (3) & (4) & (5) & (6) & ( $)$ \\
\hline $\mathbf{A}$ & Pertanian,Kehutanamn dan Perikanam & 1,07 & 1,02 & 0,95 & 0,89 & 0,83 \\
\hline B & Pertambangm dan Penggalimn & 0,00 & 0,00 & 0,00 & 0,00 & 0,00 \\
\hline C & Industri Pengolaham & 20,36 & 19,95 & 19,23 & 18,57 & 18,53 \\
\hline D & Pengadaan Listrik dan Gas & 4,79 & 4,87 & 5,45 & 5,81 & 6,74 \\
\hline $\mathbf{E}$ & $\begin{array}{l}\text { Pengadam Air, Pengolahan Sampah dan Daur } \\
\text { Ulang }\end{array}$ & $\mathbf{0 , 1 0}$ & 0,10 & 0,11 & 0,11 & 0,10 \\
\hline $\mathbf{F}$ & Kontruksi & 11,39 & 11,19 & 11,27 & 11,38 & 11,27 \\
\hline $\mathbf{G}$ & $\begin{array}{l}\text { Perdagangan Besar dan Eceran; Reparasi Mobil } \\
\text { dan Sepeda Motor }\end{array}$ & 22,50 & 22,73 & 22,75 & 22,75 & 22,25 \\
\hline $\mathbf{H}$ & Transportasi dan Pergudangan & 10,79 & 10,80 & 10,96 & 11,11 & 10,83 \\
\hline $\mathbf{I}$ & Penyediaan Akomodasi dan Makan Minum & 4,42 & 4,39 & 4,36 & 4,49 & 4,45 \\
\hline $\mathbf{J}$ & Informasi dan Komunikasi & 4,05 & 4,30 & 4,31 & 4,17 & 4,41 \\
\hline $\mathbf{K}$ & Jasa Keumgan dan Asurmsi & 6,59 & 6,59 & 6,55 & 6,93 & 6,79 \\
\hline $\mathbf{L}$ & Real Estat & 2,12 & 2,16 & 2,20 & 2,23 & 2,24 \\
\hline M,N & Jasa Perusaham & 1,86 & 2,01 & 2,03 & 2,05 & 2,04 \\
\hline $\mathbf{0}$ & $\begin{array}{l}\text { Administrasi Pemerintah, Pertahaman dan } \\
\text { Jaminan Sosial Wajib }\end{array}$ & 3,12 & 3,18 & 3,21 & 3,02 & 3,03 \\
\hline $\mathbf{P}$ & Jasa Pendidikan & 2,33 & 2,33 & 2,48 & 2,54 & 2,59 \\
\hline $\mathbf{Q}$ & Jasa Kesehatan dan Kegiatan Sosial & 1,11 & 1,09 & 1,06 & 1,04 & 1,09 \\
\hline R,S,T,U & Jasa Lainnya & 3,38 & 3,30 & 3,10 & 2,94 & 2,81 \\
\hline & PDRB Tetrl & I0,e & 10,e & In,es & 10,e & 10,e \\
\hline
\end{tabular}

Sumber: BPS Kota Bogor, 2015 


\section{PERUMUSAN STRATEGI}

\section{Tingkat Peranan Faktor dalam Meningkatkan Efisiensi dan Efektivitas Kinerja Keuangan Pemerintah Kota Bogor.}

Perbandingan antar elemen
"Faktor" berdasarkan Meningkatkan efisiensi dan efektivitas kinerja keuangan pemerintah Kota Bogor, yaitu urutan pertama perencanaan dengan nilai 0,298 urutan selanjutnya secara berturut-turut adalah sistem/mekanisme dan sumber daya manusia (SDM) dengan nilai 0,246 dan dukungan kelembagaan dengan nilai 0,210 . Perencanaan dinilai sebagai prioritas pertama dibandingkan faktor lainnya dikarenakan perencanaan dalam sebuah organisasi adalah sangat penting terutama dalam organisasi sektor publik dalam menyusun programprogram yang sesuai dengan kebutuhan organisasi tersebut. Perencanaan yang matang, jelas dan terukur akan berdampak pada penggunaan anggaran pendapatan dan belanja daerah (APBD) yang tepat sasaran.

\section{Tingkat Peranan Aktor dalam Meningkatkan Efisiensi dan Efektivitas Kinerja Keuangan Pemerintah Kota Bogor.}

Dari hasil AHP, perbandingan antar unsur "Aktor" berdasarkan "Faktor" yaitu prioritas pertama DPRD dengan nilai 0,351 . Prioritas kedua adalah badan perencanaan pembangunan daerah (Bappeda) dengan nilai 0,250. Prioritas selanjutnya sekretariat daerah (Setda) dengan nilai 0,218 dan yang terakhir adalah dinas pendapatan daerah (Dispenda) dengan nilai 0,181. DPRD dinilai memiliki kekuatan dan peluang yang lebih besar dibanding stakeholder lainnya dalam hal penentuan strategi meningkatkan efisiensi dan efektivitas kinerja keuangan pemerintah Kota Bogor dikarenakan fungsi yang dimiliki oleh DPRD yang diatur didalam UU Nomor 27 tahun 2009 tentang susunan dan kedudukan MPR/DPR-RI, DPD-RI dan DPRD dimana DPRD memiliki fungsi anggaran yang berwenang untuk membahas dan memberikan persetujuan atau tidak memberikan persetujuan terhadap RAPBD yang diajukan oleh kepala daerah.

\section{Tingkat Peranan Tujuan dalam Meningkatkan Efisiensi dan Efektivitas Kinerja Keuangan Pemerintah Kota Bogor.}

Perbandingan antar elemen "Tujuan" berdasarkan "Aktor" yaitu urutan pertama meningkatkan penyerapan belanja daerah dengan nilai 0,729 dan urutan selanjutnya optimalisasi pendapatan daerah dengan nilai 0,271. Responden berpendapat bahwa dengan meningkatkan penyerapan belanja daerah terlebih dahulu dapat mendorong terciptanya multiplier effect terhadap ekonomi. Kegagalan dalam meningkatkan penyerapan belanja daerah akan berakibat hilangnya manfaat belanja. Karena belanja daerah yang telah dialokasikan ternyata tidak semua dapat dimanfaatkan yang berarti terjadi dana yang menganggur, dan apabila hal tersebut terjadi maka telah terjadi inefektivitas belanja.

\section{Tingkat Strategi dalam Meningkatkan Efisiensi dan Efektivitas Kinerja Keuangan Pemerintah Kota Bogor.}

Perbandingan antar "Strategi" berdasarkan "Tujuan" adalah urutan pertama meningkatkan pengawasan dengan nilai 0.358 , urutan kedua pendidikan dan pelatihan dengan nilai 0.193, urutan ketiga komunikasi dan komitmen pencapaian sasaran dengan nilai 0.184 , urutan keempat penerapan regulasi insentif dan disinsentif dengan nilai 0.181 dan yang kelima adalah intensifikasi dan ekstensifikasi pajak dan retribusi daerah dengan nilai 0.086. Dari hasil perhitungan dengan AHP (lampiran) ditunjukkan bahwa yang menjadi prioritas pada masing-masing level adalah seperti disajikan pada Gambar 8 . 


\section{IMPLIKASI KEBIJAKAN}

\section{Meningkatkan Pengawasan}

Berdasarkan hasil wawancara dengan para pakar meningkatkan pengawasan merupakan strategi pertama yang harus diterapkan untuk bisa menerapkan strategi-strategi pendukung yang lainnya. Seperti yang telah di ketahui dari hasil analisis rasio tingkat efektivitas belanja daerah pemerintah Kota Bogor baru berada pada tingkat cukup efektif. Selama empat tahun terakhir efektivitas penyerapan anggaran belanja pemerintah kota Bogor yang tidak terserap rata-rata sebesar Rp 93,58 miliar per tahun. Rendahnya efektivitas penyerapan anggaran belanja daerah pada pemerintahan Kota Bogor disebabkan oleh: 1) lemahnya perencanaan awal terkait penganggaran atas kebutuhan barang dan jasa yang akan dibeli dan 2) tidak optimalnya pengawasan atas pengadaan barang dan jasa itu sendiri. Kelemahan perencanaan akan berakibat pada dibelinya barang/jasa yang sebenarnya tidak dibutuhkan, yang pada akhirnya mengakibatkan kekhawatiran untuk mengeksekusinya yang berdampak pada rendahnya penyerapan anggaran belanja daerah. Pengawasan merupakan suatu rangkaian kegiatan pemantauan dan evaluasi terhadap pelaksanaan kebijakan publik. Pengawasan dilakukan untuk menjamin semuan kebijakan program dan kegiatan yang dilakukan sesuai aturan yang berlaku.

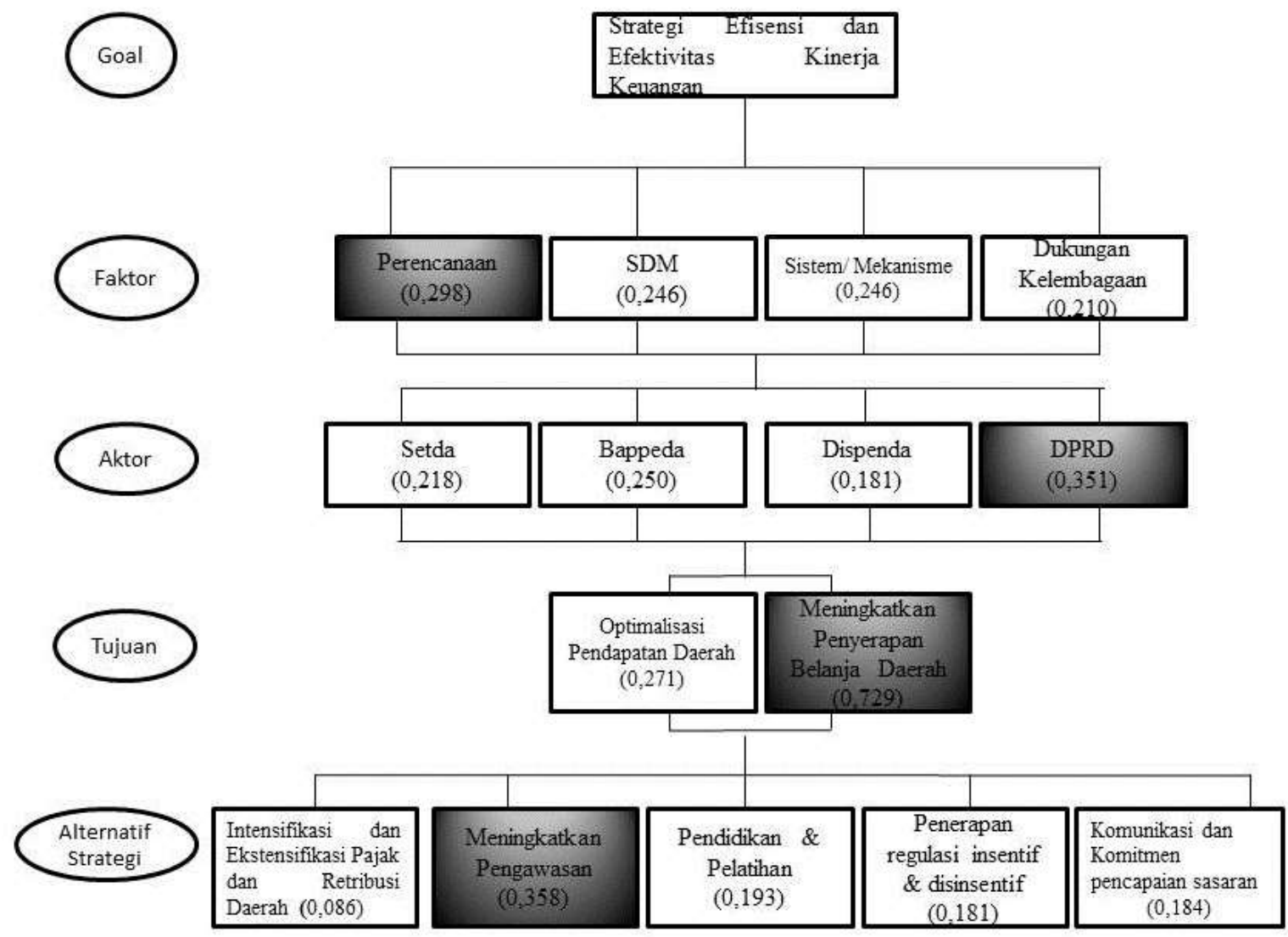

Gambar 8. Struktur Dan Nilai Bobot Hirarki AHP Strategi Meningkatkan Efisiensi Dan Efektivitas Kinerja Keuangan Pemerintah Kota Bogor.

Fungsi pengawasan merupakan salah satu fungsi terpenting DPRD dalam penyelenggaraan pemerintahan daerah.
Pengawasan keuangan daerah dilakukan oleh DPRD yang berfokus kepada pengawasan terhadap pelaksanaan 
APBD. Pengawasan terhadap pelaksanaan APBD wujudnya adalah dengan melihat, mendengar dan mencermati pelaksanaan APBD yang dilakukan oleh SKPD, baik secara langsung maupun berdasarkan informasi yang diberikan oleh kostituen.

Penguatan fungsi pengawasan ini dapat dilakukan salah satunya melalui optimalisasi fungsi dan peran DPRD sebagai kekuatan penyeimbang (balance of power) bagi eksekutif daerah. Beberapa kegiatan yang bisa di implementasikan pada strategi ini antara lain (1) Membentuk tim evaluasi dan pengawsan penyerapan anggaran di seluruh unit kerja atau SKPD, (2) Melakukan pengawasan umpan balik (Feedback Control) yaitu pengawasan yang dilakukan untuk mengukur hasilhasil dari suatu kegiatan yang dilakukan oleh unit kerja atau SKPD apakah telah sesuai dengan yang di rencanakan.

\section{Pendidikan dan Pelatihan}

Kuantitas sumber daya manusia (SDM) menjadi faktor yang berpengaruh terhadap optimaslisasi PAD. Kebijakan pemerintah pusat yang melakukan moratorium terhadap rekrutmen CPNS baru menyebabkan pemerintah Kota Bogor tidak dapat mengoptimalkan penerimanaan PAD nya disebabkan jumlah PNS pada dinas pendapatan daerah (Dispenda) yang terbatas. Keterbatasan jumlah PNS pada Dispenda Kota Bogor menyebabkan kesulitan dalam menjangkau dan melayani wajib pajak yang terus bertambah. Komposisi anggaran belanja daerah pemerintah Kota Bogor selama selama empat tahun tahun terakhir yang didominasi oleh belanja pegawai dengan rata-rata 52,42 persen dimana hal tersebut sangat membebani APBD. Untuk mengatasi hal tersebut dapat dilakukan dengan program pemindahan PNS dari SKPD lain dan selanjutnya memberikan pendidikan dan pelatihan tentang pengelolaan pajak daerah untuk meningkatkan kompetensi petugas pajak daerah yang baru .

Selain itu pengetahuan anggota DPRD mengenai anggaran sangat berpengaruh terhadap fungsi pengawasan keuangan daerah (APBD) yang dilakukan oleh anggota dewan. Perubahan mendasar dalam pengelolaan keuangan daerah (APBD) yaitu perubahan sistem penganggaran dari traditional budget ke performance budget menuntut pemahaman anggota dewan tentang fungsi penganggaran. Pendidikan dan pelatihan terhadap PNS dan anggota dewan tentang keuangan daerah diharapkan dapat meningkatkan kinerja dan kompetensi pegawai negeri sipil dan anggota dewan dalam pengelolaan keuangan daerah (APBD). Menyesuaikan kondisi yang diketahui dari hasil survei pada penelitian ini, maka beberapa kegiatan yang dapat di implementasikan dari strategi ini antara lain: (1) Pemberian beasiswa bagi para PNS untuk melanjutkan studi, (2) Mengadakan diklat-diklat tentang keuangan daerah seperti : diklat simda (sistem informasi manajemen daerah), diklat barang dan jasa, diklat bendahara, (3) Bimbingan teknis anggaran pada badan anggaran (Banggar) DPRD.

\section{Komunikasi dan Komitmen Pencapaian Sasaran}

Keberhasilan

efektivitas penyerapan anggaran belanja daerah salah satunya dipengaruhi dari keberhasilan pengendalian organisasi pada tindakan pimpinan puncak dan kemampuan mereka di dalam membangun hubungan interpersonal antar berbagai tingkat hierarki. Melalui proses penganggaran maka akan mendorong terjadinya koordinasi, kerjasama, komunikasi antar SKPD dengan cara menghubungkan masingmasing tujuan dari SKPD demi terciptanya tujuan bersama untuk mencapai sasaran dan sebaliknya ketidakadaan saling komunikasi dan 
komitmen antar SKPD dapat mengakibatkan terhambatnya SKPD dalam pengimplementasian program kerja pemerintah. Oleh karena itu, perlu kiranya pimpinan SKPD untuk menata ulang alur komunikasi antar SKPD agar semua informasi dan program kerja yang akan dilaksanakan bisa tersosialisasi dengan baik dan lancar sehingga tidak ada lagi anggaran yang tidak terserap dikarenakan kurang harmonisnya komunikasi antar SKPD. Badan perencanaan pembangunan daerah (Bappeda) menjadi aktor yang berperan didalam mengkonsolidasikan masingmasing tujuan dari SKPD sehingga diharapkan dapat meningkatkan efektivitas penyerapan anggaran belanja daerah.

$\begin{array}{llrr} & \text { Komitmen } & \text { pencapaian sasaran } \\ \text { juga menjadi } & \text { salah satu dalam } \\ \text { keberhasilan } & \text { dalam } & \text { efektivitas }\end{array}$
penyarapan anggaran belanja daerah. Penetapan APBD harus dilakukan tepat waktu agar program kegiatan dan pembangunan yang direncanakan terealisasi pada tahun anggaran sehingga pemberian pelayanan publik terhadap masyarakat dapat berjalan lancar. Lambatnya pengesahan APBD tahun 2016 yang baru disahkan pada bulan Januari 2016 dari yang seharusnya paling lambat Desember 2015 merupakan cerminan dari lemahnya komitmen eksekutif dan legislatif untuk memenuhi kewajibanya sebagai pejabat daerah yang bertugas untuk mensejahterakan masyarakat. Fenomena keterlambatan pengesahan APBD tahun 2016 mencerminkan rendahnya komitmen pencapaian sasaran baik eksekutif maupun legislatif dalam menjalankan amanah dan tugas pemerintahan. Hal tersebut dapat di hindari jika seandainya adanya dukungan kelembagaan melalui komunikasi yang baik dan komitemen bersama antara lembaga eksekutif dan lembaga legislatif dalam pencapaian sasaran dalam pengelolaan APBD. Beberapa kegiatan yang bisa di implementasikan pada strategi ini antara lain (1) Membentuk Forum SKPD merupakan arena strategis dalam menentukan prioritas pembangunan sektoral terutama untuk SKPD yang paling terkait dengan pelayanan publik. Pada pelaksanaan forum SKPD ini dipergunakan pendekatan perencanaan partisipatif (bottom-up) yang berasal dari hasil musrenbang kecamatan dengan pendekatan teknokratis yang dikembangkan SKPD atau gabungan SKPD berdasarkan kebijakan dan program prioritas pemerintah. Pendekatan perencanaan tadi menjadi dasar dalam membuat kesepakatan terkait dengan prioritas pembangunan SKPD, (2) Membentuk Forum Konsultasi antara pimpinan DPRD, Walikota dan SKPD.

\section{Penerapan Regulasi Insentif dan Disinsentif}

Strategi penerapan regulasi insentif dan disinsentif menjadi pilihan selanjurnya yang dipilih oleh para pakar. Pemberian insentif diberikan kepada para PNS yang berkinerja baik dalam hal memberikan pelayanan publik, penyerapan anggaran, dan mencapai target penerimaan PAD. Insentif ini bertujuan sebagai bentuk penghargaan atas kinerja dan untuk memotivasi PNS dalam bekerja. Hal ini timbul dikarenakan adanya anggapan didalam birokrasi bahwa yang bekerja dan yang tidak bekerja penghasilan sama. Gibson et al (1995) dalam teori motivasinya menyebutkan bahwa gaji atau upah dan berbagai tunjangan lainnya merupakan salah satu faktor kondisi ekstrinsik yang mempengaruhi sikap dan prilaku orang dalam organisasi. Apabila kondisi ini tidak ada dalam pekerjaan maka akan menyebabkan rasa tidak puas (dissatisfaction) diantara pegawai. Oleh karena itu sistem kompensasi (gaji,upah, tunjangan, insentif dan penghargaan lainnya) dalam organisasi dirancang dengan tujuan antara lain adalah memotivasi atau mendorong semangat 
pegawai mencapai prestasi yang tinggi. Kegiatan yang bisa di implementasikan pada strategi ini yaitu: Penerapan peraturan walikota Bogor tentang pemberian tunjangan keuangan daerah (TKD).

\section{Intensifikasi dan Ekstensifikasi Pajak dan Retribusi Daerah}

Salah satu ukuran kemampuan daerah untuk melaksanakan otonomi daerah adalah dengan melihat besarnya PAD yang dapat dicapai oleh daerah tersebut. Dengan PAD yang relatif kecil akan sulit bagi daerah tersebut untuk melaksanakan proses penyelenggaraan pemerintahan dan pembangunan secara mandiri tanpa didukung oleh pihak lain (dalam hal ini pemerintah pusat dan provinsi). Berdasarkan rasio tingkat ketergantungan keuangan daerah pemerintah Kota Bogor memiliki tingkat ketergantungan keuangan daerah yang sangat tinggi kepada pemerintah pusat. Oleh sebab itu diperlukan strategi intensifikasi dan ekstensifikasi pajak dan retribusi daerah sebagai cara untuk mengoptimalkan pendapatan asli daerah (PAD). Intensifikasi pajak adalah kegiatan yang dilakukan untuk menambah jumlah penerimaan dari wajib pajak yang sudah terdaftar sebagai wajib pajak daerah sedangkan proses pelaksanaan intensifikasi pajak daerah dimulai dari melakukan pembinaan, sosialisasi peraturan terkait pajak daerah, pengawasan sekaligus melakukan pemeriksaan dalam rangka meningkatkan kesadaran dan kepatuhan wajib pajak dalam melakukan kewajiban perpajakan daerahnya sesuai dengan peraturan dan ketentuan yang berlaku dan juga khusunya untuk meningkatkan penerimaan pajak daerah.

Ekstensfikasi dimulai dari proses pendataan dan pengawasan serta melakukan sosialisasi peraturan dan ketentuan yang berlaku terkait pajak daerah kepada pelaku usaha yang usahanya menjadi objek pajak daerah yang belum terdaftar dan tentunya belum melaksanakan kewajiban pajaknya ini dilakukan agar pelaku usaha segera mendaftarkan diri sebagai wajib pajak daerah. Beberapa kegiatan yang bisa di implementasikan pada strategi ini antara lain (1) Membentuk satuan tugas khusus ekstensifikasi pajak dan retribusi daerah yang terintergrasi yang bertanggung jawab untuk proses pelaksanaannya di daerah, (2) Mengoptimalkan kinerja dinas pendapatan daerah sebagai pengelola dan pelayanan pendapatan daerah, Melaksanakan sosialisasi khususnya kepada para wajib pajak daerah untuk meningkatkan kesadaran untuk membayar pajak, (4) Membuat sistem pembayaran dan pelaporan secara online (E-SPTPD) yang memudahkan para wajib pajak melaksanakan kewajiban perpajakan daerahnya, (5) Audit pajak daerah, (6) Menambah sarana dan prasarana organisasi dan sistem tata kelola pendapatan daerah

\section{SIMPULAN}

Berdasarkan hasil dan pembahasan yang telah disajikan sebelumnya, dapat disimpulkan beberapa hal sebagai berikut:

1. Berdasarakan analisis kinerja keuangan daerah, secara umum dapat digambarkan bahwa kinerja keuangan pemerintah Kota Bogor pada tahun anggaran 2005-2014 menunjukkan rata-rata kinerja keuangan daerah yang masih belum stabil atau belum baik. Hal ini ditunjukkan oleh indikator kinerja keuangan antara lain: desentralisasi fiskal kurang mengingat ketergantungan keuangan terhadap pemerintah pusat sangat tinggi dan tingkat kemandirian keuangan daerah sedang, PAD dan belanja operasional menunjukkan tren positif dimana mengalami peningkatan pertumbuhan dan alokasi belanja rutin rata-rata 59.75 persen dari belanja daerah Kota Bogor. 
2. Faktor-faktor yang berpengaruh terhadap kinerja keuangan pemerintahan Kota Bogor adalah investasi, pendapatan perkapita dan pajak daerah berpengaruh positif dan signifikan terhadap kinerja keuangan pemerintah Kota Bogor. PDRB berpengaruh negatif dan signifikan terhadap kinerja keuangan pemerintah Kota Bogor.

3. Strategi meningkatkan efisiensi dan efektivitas kinerja keuangan pemerintah Kota Bogor dalam pengelolaan APBD yang dianalisis dengan AHP, sesuai urutan prioritasnya adalah sebagai berikut: (a) Meningkatkan pengawasan, Pendidikan dan pelatihan, (c) Komunikasi dan komitmen pencapaian sasaran, (d) Penerapan regulasi insentif dan disinsentif, (e) Intensifikasi dan ekstensifikasi pajak dan retribusi daerah.

\section{SARAN}

Beberapa hal yang dapat disampaikan sebagai saran antara lain:

1. Berdasarkan rasio ketergantungan keuangan daerah dalam kurun waktu tahun 2005-2014 tingkat ketergantungan keuangan pemerintah Kota Bogor terhadap bantuan keuangan pemerintah pusat sangat tinggi. Untuk mengurangi tingkat ketergantungan keuangan, pemerintah Kota Bogor harus mampu untuk meningkatkan PAD melalui strategi intensifikasi dan ekstensifikasi pajak dan retribusi daerah. Program yang direkomendasikan berdasarkan penelitian ini salah satunya adalah membuat sistem pembayaran dan pelaporan online (E-SPTPD) untuk memudahkan para wajib pajak melaksanakan kewajiban perpajakan daerahnya.

14 2. Berdasarkan rasio aktivitas dalam kurun waktu tahun 2005-2014 alokasi belanja rutin lebih tinggi daripada belanja operasional dengan rata-rata 59.75 persen pertahun. Alokasi belanja operasional yang digunakan untuk menggerakan ekonomi, memberikan pelayanan kesehatan dan pendidikan bagi masyarakat Kota Bogor jauh lebih kecil yang hanya sekitar 40.25 persen pertahun. Untuk itu pemerintah Kota Bogor perlu mengupayakan untuk meningkatan rasio belanja operasional agar kesejahteraan masyarakat lebih meningkat dengan cara meningkatkan alokasi belanja operasional dengan porsi alokasi yang lebih besar.

3. Rata-rata anggaran yang tidak terserap pada APBD Kota Bogor sebesar Rp 93,58 miliar pertahun. DPRD Kota Bogor perlu meningkatkan fungsi pengawasan sebagai kekuatan penyeimbang (balance of power) bagi eksekutif agar penyerapan belanja daerah di Kota Bogor meningkat sehingga dapat mendorong terciptanya mutliplier effect bagi pertumbuhan ekonomi di Kota Bogor. Program yang direkomendasikan berdasarkan penelitian ini salah satunya adalah membentuk tim evaluasi dan pengawasan penyerapan anggaran di seluruh unit kerja atau SKPD.

\section{DAFTAR PUSTAKA}

Abimanyu A. 2005. Format Anggaran Terpadu Menghilangkan Tumpang Tindih. Jakarta (ID): Bapeki Depkeu.

Badan Pusat Statistik Jawa Barat. 2015. Statistik Keuangan Pemerintah Daerah Provinsi dan Kabupaten/Kota di Jawa Barat, BPS Jawa Barat, Bandung.

Basir A. 2009. Analisis faktor-Faktor yang Mempengaruhi Kapasitas Fiskal Daerah Kota Parepare. [Tesis]. Makassar (ID): Universitas Hasanuddin.

Bisma IDG, Hery S. 2010. Evaluasi Kinerja Keuangan Daerah 
Pemeritnah Provinsi Nusa

Tenggara Barat Tahun Anggaran 2003-2007. Ganec Swara. 4(3): 75-86.

BPKAD. 2015. Laporan Realisasi APBD Kota Bogor 2005 s/d 2014. BPKAD Kota Bogor. Bogor.

Chirieleison C, Montrone A. 2013. Evaluating Local Government Costs and Revenue: The Case Of An Italian Privately Owned ForProfit Event. Tourism Management Perspectives. VolMardiasmo. 2002. Otonomi dan Manajemen (8):90-

97.doi:10.1016/2013.08.001

Florida A. 2006. Pengaruh Pendapatan Asli Daerah (PAD) terhadap Kinerja Keuangan Pemerintah Kabupaten dan Kota di Provinsi Sumatra Utara. [Tesis]. Medan (ID): Universitas Sumatra Utara.

Galariotis E, Guyot A, Doumpos M, 2015. A Novel Multi-Attribute Benchmarking Approach For Assessing The Financial Performance Of Local governments: Empirical Evidence From France. European Journal Of Operational Research. 117.doi:10.1016/j.ejor.2015.06.042

Han L, Kung JKS.2015. Fiscal Insntives And Policy Choice Of Local Government: Evidance From China. Journal Of Development Economics. Vol (15): 3043878.doi:10.1016/2015.04.003.

Lajdin N. 2008. Analisis Kemandirian Fiskal Di Era Otonomi Daerah (Studi Kasus di Provinsi Sulawesi Selatan).[Tesis]. Semarang (ID): Universitas Dipenogoro.
Mahmudi. 2009. Manajemen Keuangan

Daerah. Yogyakarta (ID): Erlangga.

Mahmudi. 2010. Analisis Laporan Keuangan Pemerintah DaerahPanduan Bagi Eksekutif, DPRD, dan Masyarakat Dalam Pengambilan Keputusan Ekonomi, Sosial, dan Politik. Yogyakarta (ID): Unit Penerbit dan Percetakan Sekolah Tinggi Ilmu Manajemen YKPN.

Keuangan Daerah. Yogyakarta (ID) : ANDI.

Saaty TL. 1993. Pengambilan Keputusan Bagi Para Pemimpin. Setiono L, Penerjemah. Jakarta (ID): PT.Pustaka Binaman Pressindo.

Shaverdi M, Heshmati MR, Ramezani I. 2014. Application Of Fuzzy AHP Approach For Financial Performance Evaluation of Iranian Petochemical Sector. Information Technology and Quantitative Management. Vol (31): 9951004.doi:10.1016/2014.05.352

Sumenge AS. 2013. Analisis Efektivitas dan Efisiensi Pelaksanaan Anggaran Belanja Bappeda Minahasa Selatan. Jurnal EMBA.Vol (1): 74-81.

Suprajitno P. 2003. Analisis FaktorFaktor Yang Mempengaruhi Kemandirian Fiskal Daerah (Studi Kasus di Kabupaten Banjarnegara).[Tesis]. Semarang (ID): Universitas Dipenogoro. 
Lampiran hasil pengolahan Analytical Hierrarcy Process

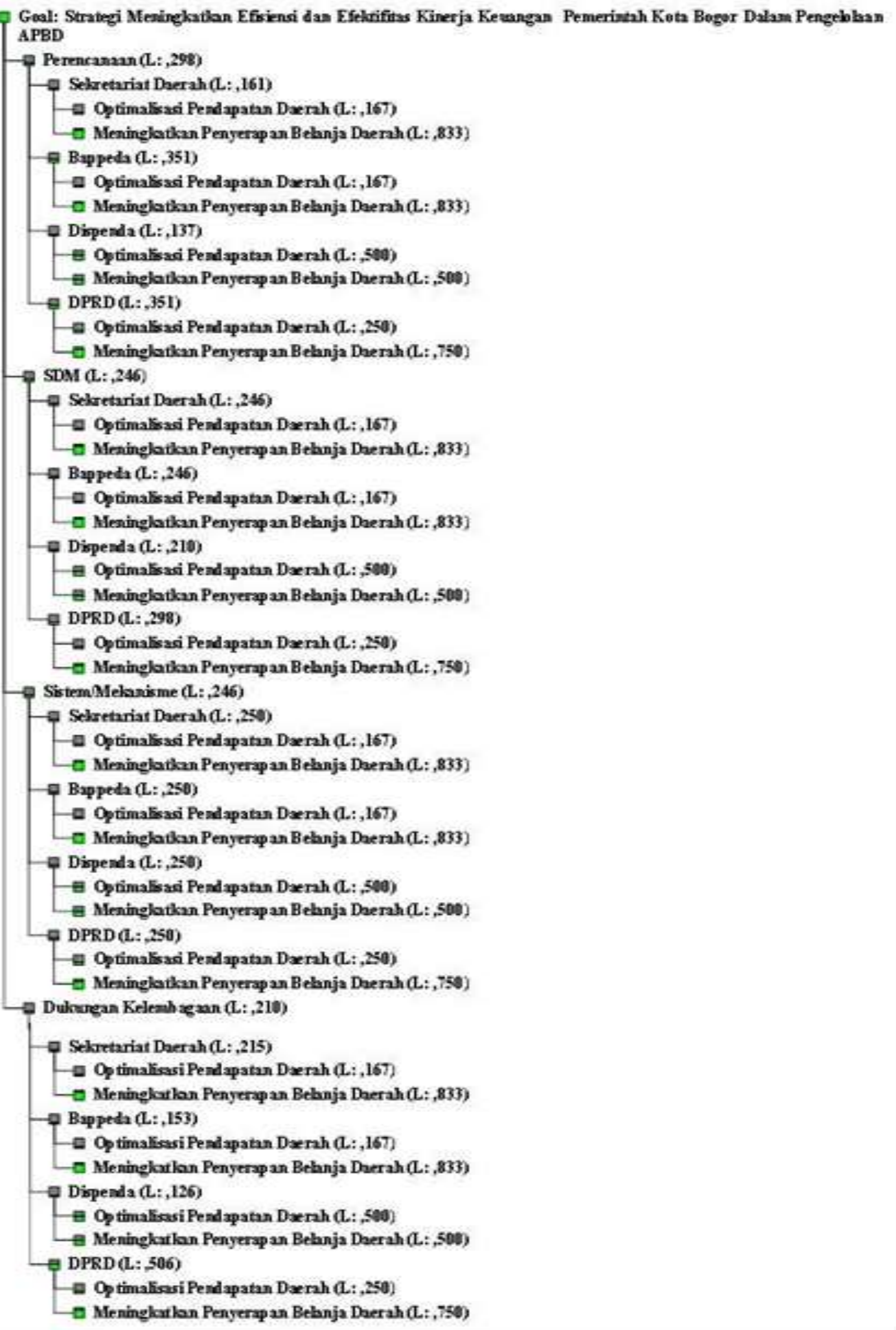

